\title{
THE CORRELATION BETWEEN AUDIO VISUAL ON BLOOD CIRCULATION MATERIAL AND LEARNING OUTCOMES OF PRIMARY STUDENTS IN MI MUHAMMADIYAH KALIKAJAR WONOSOBO
}

\author{
Risqi Fani Angraeni ${ }^{1}$, Ahwy Oktradiksa², Muis Sad Iman \\ Universitas Muhammadiyah Magelang, Indonesia ${ }^{1,2,3}$ \\ E-mail: rickyfanny616@gmail.com¹, ahwy@ummgl.ac.id², \\ muis_sad_iman@yahoo.com ${ }^{3}$
}

DOI: $\underline{10.14421 / \text { al-bidayah.v12i1.194 }}$

\begin{abstract}
The use of audio-visual media is on learning outcomes of science on circulatory material at MI Muhammadiyah Kalikajar Wonosobo. This research is a quantitative study with audio-visual media variables and variable learning outcomes of science in the blood circulation material. The population in this study was totaling 212 students. The sample in this study was 20 students. Collecting data used questionnaires, interviews, and documentation. Data analysis used product-moment correlation analysis. The results that the learning process of natural blood circulation material before using audio-visual media is less effective, the use of audio-visual media at this time in the high class is shown from the respondent's answered 55\%. Improved learning outcomes of the science of blood circulation material the Minimum completeness criteria (KKM) complete predicate as many as 16 students with a percentage of $80 \%$, and four students had not completed the KKM with a percentage of $20 \%$. The research finding obtained $\mathrm{r}^{\mathrm{xy}}$ count value of 0.489 with a significant level of $5 \%$ higher than $\mathrm{r}$ table, which means Ha was accepted Ho was rejected, namely, there was a correlation between the use of audio-visual media on studying of blood circulation science materials.
\end{abstract}

Keywords: audio-visual media; blood circular; learning outcomes

\section{INTRODUCTION}

The teachers must have complex abilities so that they can allow the learning process in class without ignoring the conditions, diversity of attitudes, characters and abilities of students in accepting learning. ${ }^{1}$ One effort to create effective atmosphere in the classroom, namely all students must accept the learning presented. ${ }^{2}$ The teacher's ability in question is the insight and skill to organize and manage all elements related to the learning process by the aims of the school curriculum.

1 Geneva Gay, “Teaching To and Through Cultural Diversity," Curriculum Inquiry 43, no. 1 (January 1, 2013): 48-70, https://doi.org/10.1111/curi.12002.

${ }^{2}$ Marie-Christine Opdenakker and Jan Van Damme, "Teacher Characteristics and Teaching Styles as Effectiveness Enhancing Factors of Classroom Practice," Teaching and Teacher Education 22, no. 1 (January 1, 2006): 1-21, https://doi.org/10.1016/j.tate.2005.07.008. 
Teachers are required to be able to develop skills in making instructional media that will be used in the media is not yet available. ${ }^{3}$ For this reason, teachers must have enough knowledge about learning media, which includes: (1) media as a communication tool to make teaching and learning more effective, (2) the function of the media to do educational goals, (3) the intricacies of the teaching and learning process, (4) the relationship between teaching methods and educational media, (5) the value or benefits of educational media in teaching, (6) the choice and use of educational media, (7) various types of educational media tools and techniques, (8) educational media in each subject, and (9) innovation efforts in educational media.

But in reality today, there are still many teachers who are found without using learning media. Often teachers only use teacher and student textbooks as a reference for teaching. As the researchers found, based on observations at MI Muhammadiyah (MIM), Kalikajar, Wonosobo, there are still many teachers who have not fully used the learning media. Even though the attendance of learning media will be able to make students effective in learning and expected with the existence of student learning media will be responsive, understanding and learning outcomes will increase. ${ }^{4}$

Based on student report cards obtained, that $60 \%$ of learning achievement in science subjects class V at MIM Kalikajar is still at least the KKM, which is 75 that has been set by MIM Kalikajar. Especially in the learning of science circulating material, students still feel confused, and learning outcomes are declining. Visible teaching and learning process takes place in one direction. Students only listen and record the lessons given by the teacher. The teacher has not used effective learning media. Apart from that, students neglect themselves and are not enthusiastic in learning. Some students are permitted to go to the bathroom because they are bored in class, and when the teacher asks questions, many students do not understand the contents of the learning that is just happening. This condition can be seen in the use of learning media, which are still prevalent in the form of blood circulation media and science textbooks.

3 Katrin Becker, "Digital Game-Based Learning Once Removed: Teaching Teachers," British Journal of Educational Technology 38, no. 3 (2007): 478-88, https://doi.org/10.1111/j.14678535.2007.00711.x.

${ }^{4}$ Jennifer F. Samson and Brian A. Collins, Preparing All Teachers to Meet the Needs of English Language Learners: Applying Research to Policy and Practice for Teacher Effectiveness, Center for American Progress (Center for American Progress, 2012), https://eric.ed.gov/?id=ED535608. 


\section{RESEARCH METHODS}

This type of research conducted at this time is a quantitative research using the same structured or systemic questions to many people, for then all answers obtained are examined and recorded, processed and analyzed, structured / systematic questions are known as questionnaires. ${ }^{5}$ This study involved a population of 212 students and simplified it into a sample of research into 20 students. Data collection techniques consisted of questionnaires, interviews, and documentation followed by tests of the validity and reliability of research instruments. The technical analysis of research was using quantitative with product-moment correlation.

\section{RESULT AND DISCUSSION}

Media is anything that can be used to channel messages from the sender to the recipient so that it can stimulate students' thoughts, feelings, concerns, and interests and attention in the learning process. ${ }^{6}$ The media is a component of learning resources or physical vehicles that contain instructional in the environment of students that can stimulate students to learn. ${ }^{7}$ The audio-visual media or audio-visual devices are "audible" which means that they can be heard and means "visible" means they can be seen. So, the audio-visual media is a media that can be heard and can also be seen by the five senses. Such as video recordings, which can be grouped in audio-visual media among them, television, interactive power point slides, interactive videos, sound films, video cassettes or CDs, and computers. ${ }^{8}$ The term audio-visual materials is commonly used to refer to those instructional materials that may be used to convey meaning without complete dependence upon verbal symbols or language. ${ }^{9}$

The development of information technology so rapidly turned out to have a broad impact on the area of teaching materials, one of which is audio-visual. These teaching materials have a variety of forms of variation; there are forms of games, questions, and

\footnotetext{
${ }^{5}$ John W. Creswell, Research Design: Qualitative, Quantitative, and Mix Methods Approaches, 3rd ed. (California: SAGE Publication, Inc., 2009).

${ }^{6}$ Sadiman, Media Pendidikan (Jakarta: Pustekom Dikbud dan PT Raja Grafindo Persada, 2012).

${ }^{7}$ Azhar Arsyad, Media Pembelajaran (Jakarta: PT Raja Grafindo Persada, 2014).

8 Daryanto, Media Pembelajaran Perananya Sangat Penting Dalam Mencapai Tujuan Pembelajaran (Yogyakarta: GAVA Media, 2013).

${ }^{9}$ Doosuur Ashaver, "The Use of Audio-Visual Materials in the Teaching and Learning Processes in Colleges of Education in Benue State-Nigeria," IOSR Journal of Research \& Method in Education (IOSRJRME) 1, no. 6 (2013): 44-55, https://doi.org/10.9790/7388-0164455.
} 
those in the form of teaching materials. This material is the positive side of information technology for education. ${ }^{10}$ The usefulness of this media is the learning process can be more interesting. Besides, the learning can be more interactive. The amount of teaching time can be reduced. The quality of student learning can be improved. Then, the learning process can be done anywhere, anytime, and student learning attitudes can be improved. ${ }^{11}$

Learning outcomes are abilities possessed by students after he has received his learning experience. ${ }^{12}$ Meanwhile, Arikunto stated that learning achievement is the level of achievement that has been achieved by students or students towards the goals set by each field of study after the teaching program in the closest time. ${ }^{13}$

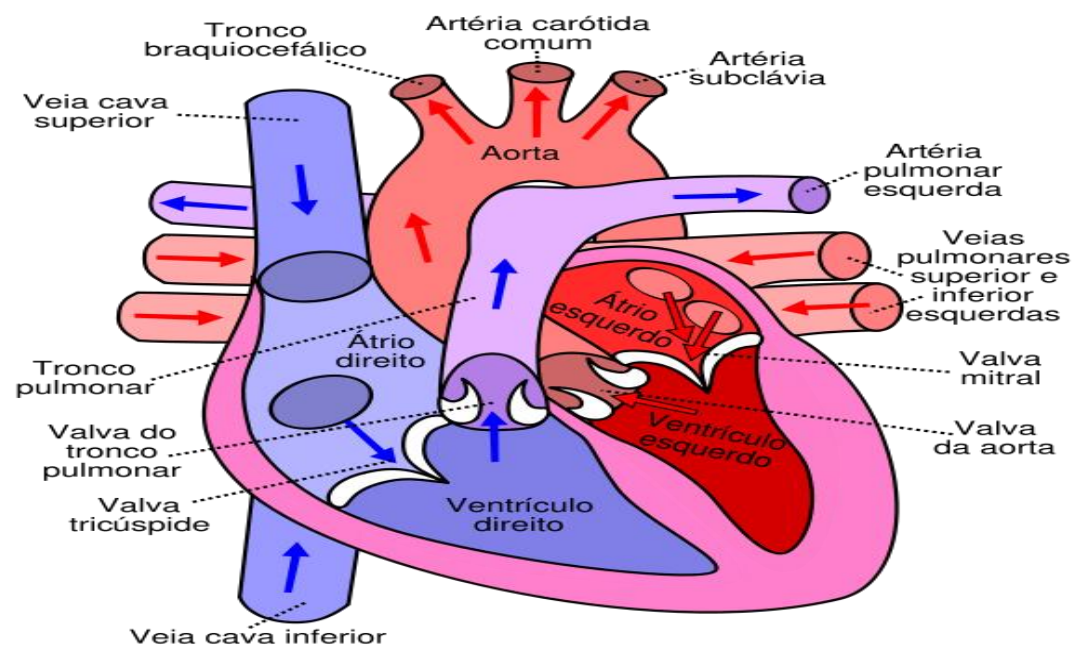

Figure. 1

Anatomy of the Heart ${ }^{14}$

Science is concerned with finding out about nature systematically, so that natural science is not only mastering a collection of knowledge in the form of facts, concepts, or principles but also is a process of discovery. ${ }^{15}$ Blood circulation is an organ system that functions to move substances to and from cells. Figure 1 shows the anatomy of the heart. The circulatory system helps stabilize body temperature and $\mathrm{pH}$ (part of homeostasis).

${ }^{10}$ Andi Prastowo, Panduan Kreatif Membuat Bahan Ajar Inovatif (Yogyakarta: DIVA Press, 2014).

11 Daryanto, Media Pembelajaran Perananya Sangat Penting Dalam Mencapai Tujuan Pembelajaran.

${ }^{12}$ Nana Sudjana, Penilaian Hasil Proses Belajar Mengajar (Bandung: Remaja Rosdakarya, 2013).

${ }^{13}$ Suharsimi Arikunto, Dasar-Dasar Evaluasi Pendidikan, (Jakarta: Bumi Aksara, 2003).

14 Rasel Hossain Md, "Anatomy of the Heart," September 11, 2012, https://id.wikipedia.org/wiki/Berkas:Anatomy_of_the_Heart.jpg.

15 Anatri Desstya, "Kedudukan Dan Aplikasi Pendidikan Sains Di Sekolah Dasar," Profesi $\begin{array}{llllll}\text { Pendidikan Dasar } & 1, & \text { no. } & 2 & \text { (2014): } & \text { 193-200., }\end{array}$ https://journals.ums.ac.id/index.php/ppd/article/viewFile/1002/679. 
There are two types of circulatory systems. The first type is the open circulatory system. Then, the second type is the closed circulatory system. The circulatory system is part of the performance of the heart, and the network of blood vessels (cardiovascular system) is formed. The system guarantees survival of the organism. The circulatory system is supported by the metabolism of every cell in the body. Besides, this system maintains the chemical and physical properties of the collapsed liquid. ${ }^{16}$

\section{Table 1}

Variable Categories Use Of Audio-Visual Media

\begin{tabular}{ccccc}
\hline No & Skor & Quatity & Procentage & Criteria \\
\hline 1. & $29-36$ & 11 & $55 \%$ & high \\
\hline 2. & $20-28$ & 7 & $35 \%$ & Middle \\
\hline 3. & $12-19$ & 2 & $10 \%$ & Low \\
\hline & Total & 20 & $100 \%$ & \\
\hline
\end{tabular}

Table 1 shows the results of the classification of respondents' answers. The explanation for the table 1 is the respondents who get scores from the number of questionnaires are 12 to 19 were two people with a percentage of $10 \%$. This amount is in a low category. The respondents who score 20 to 28 are seven persons with a percentage of $35 \%$. This amount is in the medium category. Then, the respondents who score 29 to 36 as many as 11 persons with a percentage of 55\%. This amount is in the high category. Figure 2 indicates the distribution of the responses.

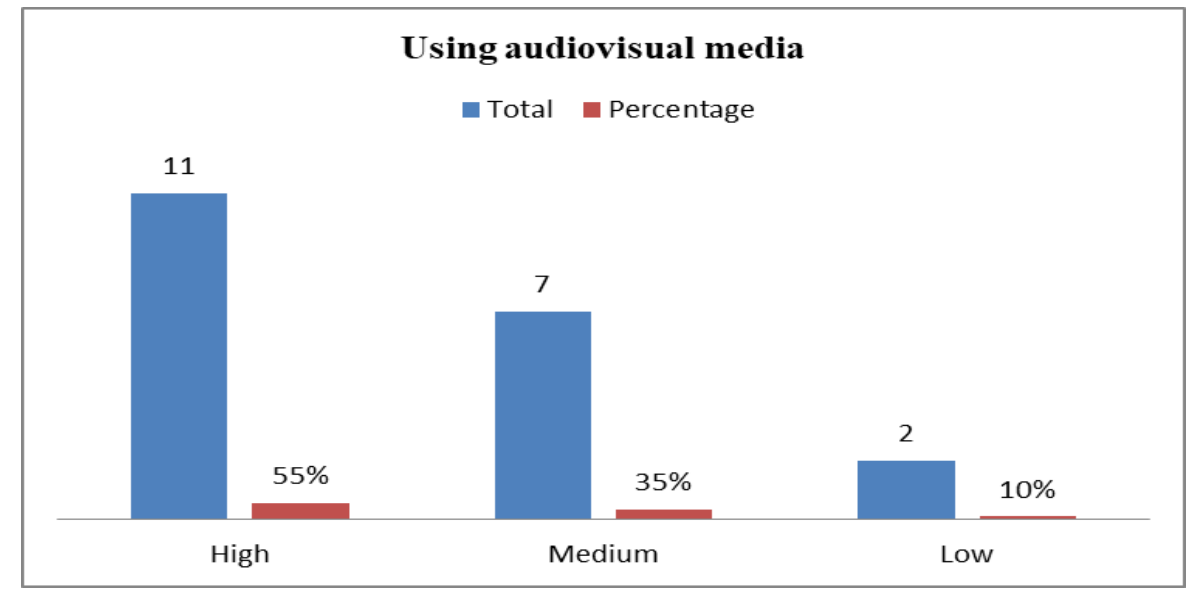

Figure 2

Distribution Of Respondents' Answers Using Audio-Visual Media

${ }^{16}$ Choiril Azmiyawati, Wigati Hadi Omegawati, and Rohana Kusumawati, IPA 5 Salingtemas Untuk Kelas V SD/MI (Jakarta: Pusat Perbukuan, Departemen Pendidikan Nasional, 2008). 
The learning outcomes of this science material are taken from the student test book about circulatory. Based on these score achievement, the science learning outcome of blood circulation material are categorized into three groups, namely high, medium, low. The division of categories uses the formula interval class that is the ideal highest value minus the ideal lowest value plus one then divided by the number of classes. The highest ideal score is obtained from the study results of the science of blood circulation material in the student test scores that is 85 , and the lowest value is 66 .

The results from the classification of respondents' answers refer to MIM Kalikajar with the KKM's score of 75, and according to the calculation of the interval can be seen from table 2.

Table 2

Variable Learning Outcomes of Science Natural Circulatory Material

\begin{tabular}{ccccc}
\hline No & Skor & Quantity & Percentage & Achievement KKM \\
\hline 1. & $75-85$ & 16 & $80 \%$ & Reached \\
\hline 2. & $66-74$ & 4 & $20 \%$ & Not reached \\
\hline & Total & 20 & $100 \%$ & \\
\hline
\end{tabular}

Based on the table 2, from 20 respondents, students who scored 75 to 85 as many as 16 students with a percentage of $80 \%$ in the KKM predicate is complete. Then, the students who scored 66 to 74 as many as four students with a percentage $20 \%$. This percentage is in the KKM predicate is not complete. Figure 3 indicates the distribution of responses from respondents.

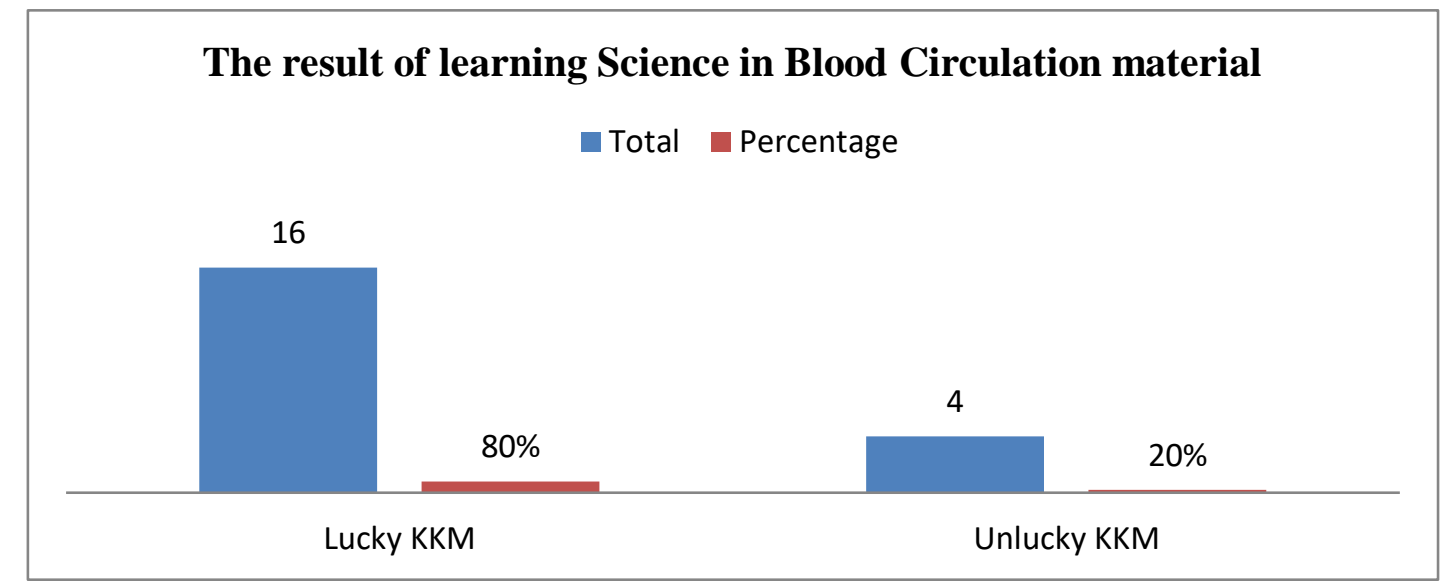

Figure 3

Distribution Of Respondents' Responses To Learning Outcomes Of Sciences In Blood Circulation Material 
According to the research data finding, the use of audio-visual media at MIM Kalikajar in the high class is based on the formulation of the questionnaire results of 20 respondents and 12 question items in which the frequency of answers is 11 students in the high class with a percentage of $55 \%$, seven students in the medium class with the percentage of $35 \%$ and two students in the low class with a percentage of $10 \%$. The natural science learning outcomes of the circulatory materials at MIM Kalikajar showed that 16 students in the KKM predicate completed with a percentage of $80 \%$, and four students in the KKM predicate not completed with a percentage of $20 \%$.

The value of rxy obtained 0.489 based on the formula $\mathrm{df}=\mathrm{N}-\mathrm{nr}=20-2=18$ is known $r$ table at $5 \%$ significance level that is 0.444 then the rxy of 0.489 is greater when compared to $\mathrm{r}$ table 5\% significance level. Thus Ha submitted. While Ho was rejected. So it can be concluded that there is a positive correlation between the use of audio-visual media on the learning outcomes of the science of circulatory material at MIM Kalikajar. The obtained rxy value from the product-moment correlation test results was 0.458 lies between $0.40-0.599$. So, based on the guidelines table, this value of the correlation coefficient which is classified as moderate or enough.

The audio-visual media is a media that can be heard and can also be seen by the five senses. This media is such as video recordings. The audio-visual media be grouped in several types are television, interactive power point slides, interactive videos, sound films, video tapes or CDs and computers. ${ }^{17}$ The audio-visual aids defined as the computer delivered combination of a large range of communications elements text, sound, graphics, pictures, photographs, animation and moving video. ${ }^{18} ;{ }^{19}$ The ability of this media is considered better and more interesting, because it has both the first and second elements

${ }^{17}$ Ghulam Shabiralyani et al., "Impact of Visual Aids in Enhancing the Learning Process Case Research: District Dera Ghazi Khan.," Journal of Education and Practice 6, no. 19 (2015): 226-33., https://eric.ed.gov/?id=EJ1079541.

18 Ali Sabah Jameel Al-Khayyat, "The Impact of Audio-Visual Aids (AVA) and Computerize Materials ( CM ) on University ESP Students ' Progress in English Language Ali Sabah Jameel Al-Khayyat Department of English Language Faculty of Education University of Anbar , Iraq Email : Alisabah4," International Journal of Education and Research 4, no. 1 (2016): 273-82., https://www.researchgate.net/profile/Ali-Al-Khayyat-4/publication/325285803_The_Impact_of_AudioVisual_Aids_AVA_and_Computerize_Materials_CM_on_University_ESP_Students'_Progress_in_Englis h_Language/links/5b03ed9c0f7e9be94bdb2243/The-Impact-of-Audio-Visual-Aids-AVA-andComputerize-Materials-CM-on-University-ESP-Students-Progress-in-English-Language.pdf.

${ }^{19}$ S. Malik and A. Agarwal, "Use of Multimedia as a New Educational Technology Tool-A Study," International Journal of Information and Education Technology 2, no. 5 (2012): 468-71, https://doi.org/10.7763/ijiet.2012.v2.181. 
of media type. Utilization of audio visual media is usually equipped with student activity sheets that guide students to utilize audio visual media in the learning process.

Thus, the use audio-visual media in natural science learning about circulatory material assisted teachers in delivering material more clearly and easy to understand. The reason was the teacher can display parts of the human body such as the heart and lungs with pictures. Besides, the teacher can explained or showed the circulation process in the human body with videos. The teachers can also summarize or create the core of the material in the book using interactive power point slides. ${ }^{20}$ Learning will be more effective and efficient so that the value of student learning outcomes will increase because students more easily understand the material.

Based on research during the field, researchers can give an illustration that the natural science learning process of blood circulation before using audio-visual media seems to be less effective. Thus, the use audio-visual media in natural science learning about circulatory material assisted teachers in delivering material more clearly and easy to understand. Meanwhile, the use of audio-visual media has now been applied well in the natural science learning class 5 about blood circulation material. This use of the audiovisual media has a positive influence and has improved student learning outcomes to be better than before. This improving can be seen from the test scores of students more than some students have reached KKM which is 75 . Meanwhile, there are only a few students who have not reached the KKM applied by MIM Kalikajar. The advantages of the use of audio-visual media in learning are the teacher can display parts of the human body such as the heart and lungs with pictures. The teacher can explained or showed the circulation process in the human body with videos. The teachers can also summarize or create the core of the material in the book using interactive power point slides.

This finding confirms the Kumar, et al., research finding. The research of Kumar, et al., has involved two hundred and eighty six from first, second and third professional medical students. The Kumar finding stated that lectures delivered by using a combination of audio visual aids are more appreciated by the students. ${ }^{21}$ This finding also

${ }^{20}$ Daniel Kuok Ho Tang and Rangis Intai, "Effectiveness of Audio-Visual Aids in Teaching Lower Secondary Science in A Rural Secondary School," Asia Pacific Journal of Educators and Education 32 (2017): 91-106, https://doi.org/10.21315/apjee2017.32.7.

${ }^{21}$ Ashutosh Kumar et al., "Students' Views on Audio Visual Aids Used during Didactic Lectures in a Medical College," Asian Journal of Medical Sciences 4, no. 2 (May 13, 2013): 36-40, https://doi.org/10.3126/ajms.v4i2.8031. 
confirms the Nurlia et.al research finding stated that audio-visual media that accompany the problem-based learning model can effect to improve the learning outcomes of class 10 students on Newton's law material and its application. ${ }^{22}$ Thus, the findings of this study reinforce the findings of previous studies which confirm that audio-visual media in learning can improve student learning outcomes in madrasah ibtidaiyah or elementary school.

\section{CONCLUSION}

Based on the analysis and discussion of research data, there is a correlation between the use of audio-visual material on blood circulation in science subjects, the results of which can increase the effectiveness of teachers and students in understanding the material. This result is evidenced by the acquisition of rxy value obtained at 0.489 . This is when compared to $r$ tables at 5\% significance level with $\mathrm{df}=\mathrm{N}-\mathrm{nr}=20-2=18 \mathrm{r}$ refers to tables of $5 \%$ significance level that is 0.444 then the rxy of 0.489 is higher when compared to $r$ tables. The obtained rxy value from the product moment correlation test was 0.489 lies between $0.40-0.599$. This data stated that the strength of the correlation between the variable use of audio visual media and the variable learning outcomes of blood circulation science material is moderate or enough category.

\section{REFERENCES}

Al-Khayyat, Ali Sabah Jameel. "The Impact of Audio-Visual Aids (AVA) and Computerize Materials ( CM ) on University ESP Students' Progress in English Language Ali Sabah Jameel Al-Khayyat Department of English Language Faculty of Education University of Anbar, Iraq Email : Alisabah4." International Journal of Education and Research 4, no. 1 (2016): 273-82. https://www.researchgate.net/profile/Ali-Al-Khayyat4/publication/325285803_The_Impact_of_AudioVisual_Aids_AVA_and_Computerize_Materials_CM_on_University_ESP_Stud ents'_Progress_in_English_Language/links/5b03ed9c0f7e9be94bdb2243/TheImpact-of-Audio-Visual-Aids-AVA-and-Computerize-Materials-CM-onUniversity-ESP-Students-Progress-in-English-Language.pdf.

Arikunto, Suharsimi. Dasar-Dasar Evaluasi Pendidikan,. Jakarta: Bumi Aksara, 2003.

Arsyad, Azhar. Media Pembelajaran. Jakarta: PT Raja Grafindo Persada, 2014.

${ }^{22}$ Siti Nurlia, I. Komang Werdhiana, and Marungkil Pasaribu, "Pengaruh Model Problem Based Learning Disertai Media Audio-Visual Terhadap Hasil Belajar Siswa Pada Materi Hukum Newton Dan Penerapannya Di Kelas X SMAN 5 Model Palu," Jurnal Kreatif Online 8, no. 1 (March 30, 2020), http://jurnal.untad.ac.id/jurnal/index.php/JKTO/article/view/15681. 
Azmiyawati, Choiril, Wigati Hadi Omegawati, and Rohana Kusumawati. IPA 5 Salingtemas Untuk Kelas V SD/MI. Jakarta: Pusat Perbukuan, Departemen Pendidikan Nasional, 2008.

Doosuur Ashaver. "The Use of Audio-Visual Materials in the Teaching and Learning Processes in Colleges of Education in Benue State-Nigeria." IOSR Journal of Research \& Method in Education (IOSRJRME) 1, no. 6 (2013): 44-55. https://doi.org/10.9790/7388-0164455.

Becker, Katrin. "Digital Game-Based Learning Once Removed: Teaching Teachers." British Journal of Educational Technology 38, no. 3 (2007): 478-88. https://doi.org/10.1111/j.1467-8535.2007.00711.x.

Creswell, John W. Research Design: Qualitative, Quantitative, and Mix Methods Approaches. 3rd ed. California: SAGE Publication, Inc., 2009.

Daryanto. Media Pembelajaran Perananya Sangat Penting Dalam Mencapai Tujuan Pembelajaran. Yogyakarta: GAVA Media, 2013.

Desstya, Anatri. "Kedudukan Dan Aplikasi Pendidikan Sains Di Sekolah Dasar." Profesi Pendidikan Dasar 1, no. 2 (2014): 193-200. https://journals.ums.ac.id/index.php/ppd/article/viewFile/1002/679.

Gay, Geneva. "Teaching To and Through Cultural Diversity." Curriculum Inquiry 43, no. 1 (January 1, 2013): 48-70. https://doi.org/10.1111/curi.12002.

Hossain Md, Rasel. "Anatomy of the Heart," September 11, 2012. https://id.wikipedia.org/wiki/Berkas:Anatomy_of_the_Heart.jpg.

Kumar, Ashutosh, Ramanuj Singh, Lalit Mohan, and Mani Kant Kumar. "Students' Views on Audio Visual Aids Used during Didactic Lectures in a Medical College." Asian Journal of Medical Sciences 4, no. 2 (May 13, 2013): 36-40. https://doi.org/10.3126/ajms.v4i2.8031.

Malik, S., and A. Agarwal. "Use of Multimedia as a New Educational Technology ToolA Study." International Journal of Information and Education Technology 2, no. 5 (2012): 468-71. https://doi.org/10.7763/ijiet.2012.v2.181.

Nurlia, Siti, I. Komang Werdhiana, and Marungkil Pasaribu. "Pengaruh Model Problem Based Learning Disertai Media Audio-Visual Terhadap Hasil Belajar Siswa Pada Materi Hukum Newton Dan Penerapannya Di Kelas X SMAN 5 Model Palu." Jurnal Kreatif Online 8, no. 1 (March 30, 2020). http://jurnal.untad.ac.id/jurnal/index.php/JKTO/article/view/15681.

Opdenakker, Marie-Christine, and Jan Van Damme. "Teacher Characteristics and Teaching Styles as Effectiveness Enhancing Factors of Classroom Practice." Teaching and Teacher Education 22, no. 1 (January 1, 2006): 1-21. https://doi.org/10.1016/j.tate.2005.07.008.

Prastowo, Andi. Panduan Kreatif Membuat Bahan Ajar Inovatif. Yogyakarta: DIVA Press, 2014.

Sadiman. Media Pendidikan. Jakarta: Pustekom Dikbud dan PT Raja Grafindo Persada, 2012. 
Samson, Jennifer F., and Brian A. Collins. Preparing All Teachers to Meet the Needs of English Language Learners: Applying Research to Policy and Practice for Teacher Effectiveness. Center for American Progress. Center for American Progress, 2012. https://eric.ed.gov/?id=ED535608.

Shabiralyani, Ghulam, Khuram Shahzad Hasan, Naqvi Hamad, and Nadeem Iqbal. "Impact of Visual Aids in Enhancing the Learning Process Case Research: District Dera Ghazi Khan." Journal of Education and Practice 6, no. 19 (2015): 226-33. https://eric.ed.gov/?id=EJ1079541.

Sudjana, Nana. Penilaian Hasil Proses Belajar Mengajar. Bandung: Remaja Rosdakarya, 2013.

Tang, Daniel Kuok Ho, and Rangis Intai. "Effectiveness of Audio-Visual Aids in Teaching Lower Secondary Science in A Rural Secondary School.” Asia Pacific Journal of Educators and Education 32 (2017): 91-106. https://doi.org/10.21315/apjee2017.32.7. 
The Correlation between Audio Visual....

54 | Al-Bidayah, Volume 12, Number 1, June 2020 